\title{
The Rediscovery of Exports by the Third World
}

\author{
by \\ Richard C. Porter \\ and \\ Charles P. Staelin
}

\author{
CRED Reprints \\ (Now Series) \\ No. 27
}
Center for Research on Economic Development
University of Michigan
Ann Arbor, Michigan 48108




\section{Center for Research on Economic Development CRED Reprints}

*No. 1. "Nigerian Government Spending on Agricultural Development: 1962/3-1966/7" by Jerome C. Wells. (The Nigerian Journal of Economic and Social Studies, November 1967, pp. 246-275)

No. 2. "Major Issues of Wage Policy in Africa" by Elliot J. Berg. (Industrial Relations in Economic Development edited by Arthur M. Ross, Macmillan, 1965, pp. 185-208)

*No. 3. "The Myth of the Amorphous Peasantry: A Northern Nigerian Case Study" by Polly Hill (Mrs. M. E. Humphreys). (The Nigerian Journal of Economic and Social Studies, July 1968, pp. 239-260)

*No. 4. "Urban Real Wages and the Nigerian Trade Union Movement, 1939-60: A Comment" by Elliot J. Berg. (Economic Development and Cultural Change, July 1969, pp. 604-617)

*No. 5. "Turkish Economic Development: The First Five Year Plan, 1963-67" by Wayne W. Snyder. (The Journal of Development Studies, October 1969, pp. 58-71)

*No. 6. "Hidden Trade in Hausaland" by Polly Hill, (MAN, Vol. 4, No. 3, September 1969, pp. 392-409)

*No. 7. "A Comment on Peter Kilby: Industrial Relations and Wage Determination" by John F. Weeks. (The Journal of Developing Areas, Vol. 3, No. 1, pp. 7-17)

*No. 8. "Measuring the Effects of Belgian Budget Policies: 1955-65" by Wayne W. Snyder. (Cahiers Economiques de Bruxelles, No. 44,1969 , pp. 527-548)

No. 9. "The Long Term Economic Development of Germany" by Wolfgang F. Stolper. Review Article of Walter G. Hoffmann, Das Wachstum der deutschen Wirtschaft, (Weltwirtschaftliches Archiv, Vol. 103, No. 2, 1969, pp. 57-61)

*No. 10. "International Financial Issues in Foreign Economic Assistance to the Less Developed Countries" by Robert M. Stern. (Economic Development and Structural Change edited by Ian G. Smith, Edinburgh University Press, 1969, pp. 47-70)

No. 11. "Money in a Developing Economy: A Reappraisal" by Wayne W. Snyder. (The Review of Economics and Statistics, Vol. LII, No. 1, February 1970, pp. 54-61)

*No. 12. "An Econometric Model of Development: Comment" by Peter Eckstein. (The American Economic Review, Vol. LX, No. 1, March 1970, pp. 227-235)

"No. 13. "Who Destabilizes Primary Product Prices?" by Richard C. Porter. (Indian Economic Journal, Vol. XVI, No. 4, April-June 1969, pp. 389-413)

*No. 14. "Two Types of Planning" by Wolfgang F. Stolper. (Schweizerische Zeitschrift für Volkswirtschaft und Statistik, Vol. 106, No. 1, 1970, pp. 45-58) 
Reprinted from FOREIGN TRADE REVIEW, Annual Number

(Jan.-March 1972)

\section{THE REDISCOVERY OF EXPORTS \\ BY THE THIRD WORLD}

by

DR. RICHARD C. PORTER

PROFESSOR OF ECONOMICS

Centre for Research on Economic Development

UNIVERSITY OF MICHIGAN

ANN ARBOR, MichigAN (USA)

and

Dr. CHARLES P. STAELIN

Centre for Research on Economic Development

UNIVERSITY OF MICHIGAN

ANN ARbor, Michigan (USA) 



\title{
THE REDISCOVERY OF EXPORTS BY THE THIRD WORLD
}

\author{
By Richard C. Porter \\ and \\ Charles P. Staelin
}

\begin{abstract}
DESPITE its theoretical limitations, empirical presumptions and internal inconsistencies, what has come to be known as the Prebisch-Singer-Myrdal theory of underdevelopment and "inwardlooking" development appeared destined to a long and effective life, even to those whom it frightened. Throughout the I950s, the plans of the underdeveloped countries reflected the theory: export estimates were mechanical projections rather than targets to be attained, and the very estimates often seemed to be included for little reason beyond the need for consistency in the import and aid accounts.
\end{abstract}

Then, as the I960s progressed, a change in the LDC attitude towards exports occurred steadily and dramatically. Development plans increasingly discussed the specific sectoral sources and geographical destinations of exports, and the policies whereby export targets were to be implemented. Trade in general and exports in particular played an ever larger part in the theories and strategies of influential development thinkers. By 1964, the conversion was -at the intellectual level at least-complete. Led by the former high priest of "inward-looking" development, Prebisch, the poor countries opened their UNCTAD thrust towards advanced-country cooperation in the LDC efforts to expand exports. Although UNCTAD was, in a limited sense, no more than a massive culmination of earlier LDC efforts to improve aid flows through various export-support programmes to be financed by the advanced economies, it was really much more. UNCTAD finally placed LDC exports-among themselves and to the advanced worldat the core of development theory and strategy.

The turnabout itself has been surprisingly sharp and rapid, but the seeds of change were being gradually and cumulatively sown throughout the post-World War II period. These seeds of change are the subject-matter of this paper. They are discussed below under five headings: (i) the growing LDC foreign exchange crisis, (ii) the encouraging overall LDC export performance, (iii) the impressive export performance of individual LDCs, (iv) growing 
doubts about the Singer-Prebisch-Myrdal thesis, and (v) the shifting focus of development strategy.

\section{LDC Foreign Exchange CRISIS}

The basic dilemma of LDC development has been that, despite their efforts to free themselves of economic dependence on the North Atlantic world, their dependence grows. Import-substitution strategies fail to lower the absolute level of imports and indeed, often fail to lower even the ratio of imports to GNP. ${ }^{1}$. The basic balance-of-payments "gap", $2 \mathrm{M}-\mathrm{A}=\mathrm{E}$, has loomed ever larger in the I950s and I960s as the final constraint on LDC growth. If import needs grow apace with GNP and aid flows fail to accelerate, GNP growth is irrevocably tied to the growth of exports. This is precisely the constraint which Prebisch and his followers had hoped to break through industrialisation and import substitution. ${ }^{\mathrm{a}}$ To the extent the ratio of imports to GNP can be reduced, the economy's overall growth is freed from its dependence on the growth of exports and aid.

The "theory", being no more than a tautology, is no less true today than when its first rough formulations began to appear nearly a quarter of a century ago. However in most countries, industrialisation has in fact failed to reduce imports substantially either absolutely or in relation to GNP. Rather, industrialisation has tended to retard the growth of exports, and import dependence, instead of abating, has increased.

1 For example, H. Chenery and A. Strout, "Foreign Assistance and Economic Development", American Economic Review, Sept. 1966, found that the median marginal import ratio (to change of GNP) is no lower than the median average import ratio (to GNP) for the 3I LDCs they study (p. 684; their marginal ratio is calculated over 1957-62, their average is the "trend expected" I962 value).

2 i.e., imports (M) - "aid" (A) = exports (E). "Aid" means, of course, net capital account flows, public and private, long-term and short-term, grants and loans. Reduction of LDC foreign exchange reserves would also be included in "Aid", though this is a realistic possibility for few LDCs.

3 See, for instance, R. Prebisch, "Commercial Policy in the Underdeveloped Countries", American Economic Review, May 1959, pp. 252-254.

4 Maizels (Industrial Growth and World Trade, Cambridge University Press, 1963) concludes:

". . . much depends on the type of industrialisation and the general economic and monetary policy being pursued; industrialisation can just as well promote exports as retard them or, equally, have little or no significant influence 
Moreover, practical limitations have been increasingly recognised. One, lowering the import ratio is not necessarily a concomitant of the introduction of domestic industry, and two, lowering the import ratio is increasingly difficult the lower the ratio gets. The two problems are related. When import substitution begins, those industries that are easily introduced, that use relatively little imported raw materials, that require no difficult managerial or technical inputs, that are efficient at a small scale of operation-in short, those industries in which the LDC has little or no comparative disadvantage-are first established and significant foreign exchange savings may occur. As import substitution proceeds, however, the net import-saving effect dwindles and the introduction of highimport-content, high-cost industries increasingly distorts the internal price structure. ${ }^{5}$ This process makes it ever more difficult to lower the marginal import ratio, and the price distortions may even make it difficult to prevent inframarginal rises in ratio.

Statistical recognition of the problem came early, with the observation of slow, or no, declines in LDC import ratios. ${ }^{6}$ And this, coupled with the inexorable constraint, $\mathrm{M}-\mathrm{A}=\mathrm{E}$, had been creating some terrifying "gap" estimates. Given slow growth of export earnings, the Development Decade target of 5 per cent LDC growth was shown to require aid flows to fill "trade gaps" ranging as high as $\$ 15$ billion a year.? But the really terrifying aspect of such gap estimates lay in the twin facts that the gross flow of aid to LDCs was no longer expanding and that the net aid flows were

on the total export volume. It cannot therefore be assumed that industrialisation of a primary-producing country will, in itself, necessarily have adverse effects on the capacity to import ..." (p. 130).

There is general agreement, however, that certain policies which are often concomitant with industrialisation efforts, overvalued exchange rates, high tariffs and domestic price levels, and high profits in import substitution relative to exports, do retard export growth. In many countries, export promotion has been less an effort to push exports beyond their "normal" trend than a remedial attempt to prevent their decline too far below "normal".

5 See, for examples, D. Felix, "The Dilemma of Import Substitution-Argentina", in G. Papanek (ed.), Development Policy: Theory and Practice, Harvard University Press, 1968, and J. Bhagwati and P. Desai, India: Planning for Industrialisation, Oxford University Press, 1970.

- For instance, the ratio of imports to national income in India did not exhibit any falling trend over the period (calendar) I949 to 1969 (although the ratio was quite variable, year to year).

7 See, e.g., GATT, International Trade,-196r, Geneva, 1962, pp. I5-17. 
being increasingly reduced by the return flows to service existing LDC indebtedness. ${ }^{8}$

The causes of this statistical nightmare were also becoming evident. The import substitutes, towards which LDCs eventually gravitated, were requiring increasing proportions of imported raw materials and components. In some cases, it has been shown that the foreign exchange value of the import components of an LDC product is so large that it would have cost less foreign exchange to import the final product $!^{\circ}$ And in the majority of cases, the total foreign exchange saved is less-often much less - than the value of the final goods imports that have been "substituted". Even allowing for (direct and indirect) imported inputs, the savings in total imports will be overstated to the extent that domestic industry requires the acquisition of imported machinery and spare parts, or foreign licences, patents and technical assistance. Moreover, rapid increases in GNP, partly as a result of the industrialisation process itself, may mean increased consumer demand which cannot be more than partly satisfied by increased domestic production.

Thus, import "substitution" has done little to reduce the dependence on imports; in fact, to the extent the import needs are switched from consumer goods to industrial raw materials, the dependence of the production sector of the economy is increased. In times of foreign exchange stress, imports can no longer be restricted without serious direct repercussions on domestic employment, production and investment. A foreign exchange shortage, instead of encouraging the growth of domestic output, constrains it. A popular argument in the 1950s against dependence on exports was that it kept the exporter vulnerable to the vagaries of world demand; paradoxically, import substitution has intensified this vulnerability.

${ }^{8}$ Repayments of interest and principal on official bilateral loans rose from I2 per cent of gross bilateral aid flows in 1962 to 20 per cent in 1968 ; in Latin America, debt service absorbed 15 per cent of exports in 1964 versus only 6 per cent eight years earlier. See OECD, Development Assistance Efforts and Policies, various annual issues, Paris, and I. Frank, "New Perspectives on Trade and Development", Foreign Affairs, April 1967, p. 523.

- If the domestic price of an import substitute is above the world price, and if the import content is high, it may be profitable to import inputs at a total cost greater than the imported price of the final good, selling the high-cost substitute at the inflated domestic price. For evidence of this in Pakistan, see R. Soligo and J. Stern, "Tariff Protection, Import Substitution and Investment Efficiency", Pakistan Development Review, Summer 1965. For evidence in India, see J. Bhagwati and P. Desai, op. cit., pp. 352-363. 
Recognition of the inevitability of the rising cost of saving foreign exchange through import substitution came slowly, but was largely achieved by the time of UNCTAD, at least among the relatively developed of the underdeveloped nations. In the words of Prebisch:

"The simple and relatively easy phase of import substitution has reached, or is reaching, its limit in the countries where industrialisation has made most progress. As this happens, the need arises for technically complex and difficult substitution activities, which usually require great capital intensity and very large markets if a reasonable degree of economic viability is to be attained. Thus there are limits to import substitution in the developing countries which cannot be exceeded without a frequent and considerable waste of capital."10

In short, the primary reason for the LDC rediscovery of exports was no better-and no worse-than that growth in exports was increasingly recognised as essential. With imports ever more difficult to reduce (as a ratio to GNP), and with net aid flows no longer expanding adequately, the choice to many LDCs was export or stagnate; and by the early I960s this choice was abundantly clear.

\section{Overall LDC Export Performance}

Theories can be maintained in the face of facts for incredible lengths of time by reference to special circumstances. The Korean primary-product boom, clearly such a special circumstance, meant that LDC "export pessimism" could not even begin to be tested until the late I950s. As the evidence of the overall LDC export performance began to accumulate, however, it became ever nearer to impossible to maintain a posture of hopelessness about the LDC export potential.

On the major, primary-product front, the events of the later I950s were of course not exciting. The dizzying heights of the Korean years were left behind, seemingly forever, and a decadelong doldrums ensued. But doldrums differ from disaster. Within that decade, the foreign exchange earnings of most of the products, and of most of the LDCs, had reachieved their Korean peaks, and evidence had begun to pile up that demand for most of the primary

10 UN, Towards a New Trade Policy for Development, E/CONF. 46/3, UN 1964, p. 2 I. 
products was not so price-inelastic or income-inelastic as the "elasticity-pessimists" were insisting."

While the primary-product performance was nowhere near as bad as had been feared, the growth of non-primary-product exports of LDCs was undeniably encouraging. While exact measurement depends upon the period chosen and the definition of "non-primaryproduct", the trends are clear. Between 1952-53 and 1962-63, for example, "all minor exports" of 29 underdeveloped countries (i.e., those for which sufficiently detailed data were available) grew from $\$ 2.7$ billion to $\$ 4.5$ billion, an annual compound rate of growth of 5.5 per cent. Of these "all minor exports", "manufactures" grew particularly rapidly, from $\$ 0.5$ billion to $\$ 1.2$ billion, an annual rate of growth of 9.2 per cent.

As a result, the general picture for LDC exports was becoming ever more favourable. Despite the primary-product setbacks in the mid-I950s, total LDC exports grew, during 1953-54 to 1959-60, from $\$ 2$ I.6 billion to $\$ 26.6$ billion, an annual growth rate of 3.5 per cent. ${ }^{13}$ By 1965-66, however, total LDC exports had risen to $\$ 37.6$ billion, an annual growth rate of 5.9 per cent after 1959-60 and 4.7 per cent for the entire period after $1953-544^{14}$ This neardoubling of the overall growth rate of exports between the late I950s and the early I960s did not go unnoticed. Indeed, the especially encouraging performance of manufactures in the early 1960san increase of 14 per cent annually, ${ }^{15}$ leading to an increase in the LDC share of world trade in manufactures from 4.0 per cent in $1959-60$ to 4.6 per cent in $1965-66^{16}$ - was greatly responsible for the stress in UNCTAD on advanced-nation preferential tariffs to LDC manufactures.

11 See, for example, B. deVries, The Export Experience of Developing Countries, World Bank Occasional Paper No. 3, 1967, or R. Porter, "Some Implications of Post-War Primary Product Trends", Fournal of Political Economy, May-June 1970. Data show that, for two-thirds of the world's major primary products, export earnings were higher in $1960-63$ (not especially good years) than in the Korean years, 1950-53 (see deVries, op. cit., pp. 77-78).

12 The data are taken from deVries, op. cit., p. 68; the ultimate source is IMF, International Financial Statistics and UN, Yearbook of International Trade Statistics.

13 Data are from GATT, Report, 1967, Geneva, I967, p. 37.

14 Nurkse and others have pointed to the undue influence of petroleum exports on the total, arguing that petroleum exports constitute a special case. However, even without petroleum, the trends are favourable.

15 For 1960-64, according to I. Frank, op. cit., p. 532.

16 GATT, Report, r967, op. cit., p. 37. 


\section{Export Performance of Individual LDCs}

The accumulating statistics on LDC exports did not by any means show equal success for all countries. Although the list of stars and also-rans varies from year to year, the variations were far from balancing out over the decade, I950-53 to I960-63. Over this period, four $\mathrm{LDCs}^{17}-$ Greece, Jamaica, Peru and Taiwan (China)-more than doubled their export earnings, while for six others-Bolivia, Colombia, Egypt, Pakistan, Paraguay and Uruguay -export earnings fell. The variety in LDC export experience was even more "striking"18 when only "minor exports" (i.e., essentially non-primary-product exports) are examined: of the 29 LDCs in deVries' sample, twelve more than doubled their minor exports, while six experienced a decline. Thus, for only eleven of the 29 countries, did minor exports grow at a "mild" positive rate (i.e., between 0 and 7.2 per cent per year). For manufactured exports, the variation is even greater: eighteen LDCs more than doubled such exports, ${ }^{10}$ nine experienced declines, and only two had mild positive growth rates.

These observed wide variations in export growth rates would not have had much impact on LDC attitudes towards exports if successes and failures were perceived to be accidents or the exogenous results of unpredictable shifts in advanced-country demand patterns; indeed the impact might have been negative. But studies, which attempted to distinguish between controllable and uncontrollable influences on LDC exports, concluded that the wide observed variations cannot be explained simply by movements in the uncontrollable. Typically, such studies calculate the export growth (or decline) that would have occurred if the LDC had just maintained its base-year share of the world market for each of its exports. Actual export movements can then be divided into the constant-share demand vagaries and the rising-share (and new export product) influence. From such a division, it became clear that

"... the contrasting relative performances of individual countries were only relatively little influenced by the pattern of their traditional exports, being much more affected by largely supplydetermined shifts in market positions and by the development of new lines of production for export".20

17 Of deVries' 29 countries. All data in this paragraph are from deVries, op. cit., p. 68.

18 deVries' word, op. cit., p. 5.

19 Between 1952-53 and 1962-63.

20 GATT, International Trade, 1965, Geneva, 1966, p. 32. For a similar, though more cautious conclusion, see deVries, op. cit., Chap. 3. 
More than just the data suggested that export success was, to a large extent, in the hands of the LDC. The very policies of the LDCs towards exports were visible and convincing. Those LDCs that 's'made a significant effort to expand manufactured [and other] exports had remarkable success". ${ }^{21}$ Many of the policies to promote exports are largely non-quantifiable and hence difficult to assess -e.g., foreign commercial representation, quality controls and market research-but they are visible; and for the more quantifiable policy factors, evidence of their importance was steadily accumulating. For example, 'deVries' cross-country" 'regressions showed that the export "performance of countries with relatively strong inflation tends to be poor". ${ }^{22}$

There has long been an undercurrent of belief that the LDC export stagnation was in great part due to their excessive internal aggregate demand, the autarkic bias of their planning processes, ${ }^{23}$ overvalued exchange rates, and the inevitable anti-export tendencies of import-substitution policies. This collection of arguments received periodic support from two types of institutional-empirical studies, one which related secular declines in exports of particular countries to particular policies ${ }^{24}$ and the other which related cyclical swings in the exports of particular LDCs to their internal aggregate demand and real exchange rates. ${ }^{25}$

21 A. Maddison, Economic Progress and Policy in Developing Countries, Allen and Unwin, 1970, p. 205.

22 deVries, op. cit., p. 37.

${ }^{23}$ Indeed, Viner long ago maintained that all planning must be so biased:

"I have so far been claiming only that there is in government activities an inherent irrational bias towards autarky whose practical importance to national economic planning automatically increases. I go farther now, and claim that there is a strong tendency in the logic of national economic planning towards autarky".

J. Viner, International Trade and Economic Development, Oxford University Press, 1953, pp. 84-85.

24 The most important of these studies emanated from India; see M. Singh, India's Export Trends, Oxford University Press, 1964, and B. Cohen, "The Stagnation of Indian Exports, I95I-196I", Quarterly Fournal of Ecomomics, Nov. 1968.

25 See, e.g., J. Sheahan, "Imports, Investment and Growth-Colombia", pp. III-II2, in G. Papanek (ed.), op. cit., and D. Felix, "The Dilemma ...", op. cit., p. 90. The Indian recession from $1966-69$ is often credited with fostering the export boom in engineering goods and other manufactures. There is some question as to whether the substantial growth in manufactured exports targeted in the Fourth Plan is compatible with increased economic activity. 
Finally, examination of the varying export performances of LDCs showed that countries too small to flirt with import-substituting-industrialisation-at-any-cost policies were doing significantly better with their exports. In deVries' study for six of the ten large countries, ${ }^{26}$ exports were growing more slowly than the constantmarket-share rate, while for twelve of the nineteen small countries, exports were growing faster. It has become increasingly apparent that large economic size permits an LDC to ignore, for a time at least, the future of its exports and that many such large LDCs have done so. Within a decade, for example, Argentina, Brazil and India had together fallen almost one billion dollars behind their constant-market-share export levels. ${ }^{27}$

In summary, some LDCs were doing noticeably well with exports and their success was increasingly difficult to ignore. To the optimists, it indicated that adoption of a proper package of export-promotion policies could pay off handsomely in foreign exchange. But even to the pessimists, it proved that some concern for exports was needed, even where expansion seemed unpromising, if only to prevent other LDCs from infiltrating the country's existing export markets.

\section{Growing DoubTS about THE PrEBISCH- SINGER-MYRDAL THESIS}

The apparently inevitable asymmetry in the international economic relations of developed and underdeveloped countries was, despite the theoretical weaknesses of the underlying analysis, emotionally convincing in the I950s. Although persistent critiques of the PrebischSinger-Myrdal theory helped to weaken this conviction, the reluctance of emerging fact to conform was most damaging. A major concern, orrather presumption, in the discussions of the 1950s was the "notorious inelasticity of demand for primary commodities"28 with respect to both prices and incomes. However, one study of 46 primary products over the post-World War II period concluded that "demand for primary products typically may be very priceinelastic or very income-inelastic, but the common belief that it is

${ }^{26}$ deVries, op. cit., pp. 25 and 85. "Large" countries were those with GDP greater than $\$ 4$ billion in 1963 .

27 Over I950-53 to 1960-63; see deVries, op. cit., p. 25. For more detailed data on India's constant-market-shares, see Cohen, op. cit.

${ }^{28} \mathrm{H}$. Singer, "The Distribution of Gains between Investing and Borrowing Countries", American Economic Review, May 1950 (reprinted in J. Theberge, Economics of Trade and Development, John Wiley and Sons, 1968, p. 242). 
both price-inelastic and income-inelastic is not supported by the data".29

More generally, the Singer-Prebisch-Myrdal thesis was concerned with the inevitable deterioration of the terms of trade for primary producers. "The" terms of trade has been the object of economists' opinions, theories and empirical studies for over half a century, and it was not long before Prebisch's speculations were put in perspective as but one more such effort. Indeed, Prebisch's expectations were seen to run counter to typical earlier thought, which maintained that diminishing returns to primary production would cause LDC terms of trade to rise secularly. And the evidence that accumulated-even more rapidly than before, for both Prebisch's supporters and detractors worked diligently-continued to give support to either, or neither, theory. While the results varied for different concepts and coverage, broad conclusions were that the LDC terms of trade, in the late I950s, had (a) worsened relative to the early I950s, (b) improved relative to the mid-1930s, and (c) remained about the same relative to the I920s. ${ }^{30}$ Studies of particular LDCs also failed to give consistent support to the Prebisch conjecture. And finally', studies of particular primary products again failed to show any consistent trends.

These empirical findings on LDC terms of trade were continually faced by theoretical polemics of three kinds. One, many economists of stature such as Haberler, Viner and Cairncross spoke out frequently, encyclopaedically and convincingly against the decliningterms-of-trade argument. As an example of their vehemence:

"... I find myself almost entirely out of sympathy: the world economy is not so constructed that primary-producing countries are doomed to a degringolade in their terms of trade with industrial countries..."

A not too exaggerated parody of their diatribe would run: the terms of trade are not turning against the LDCs; but even if they are, they are not turning against all LDCs; but even if they are, the gains from trade are not necessarily measured by the terms of trade; etc.

${ }^{29}$ R. Porter, "Some Implications of Post-War Primary Product Trends", op. cit., p. 586.

30 See, e.g., GATT, Trends in International Trade, Geneva, 1958, p. 20, and T. Morgan, "Trends in the Terms of Trade and Their Repercussions on Primary Producers", in R. Harrod and D. Hague (eds.), International Trade Theory in a Developing World, MacMillan, 1963. This latter contains a good review of the terms-of-trade theories and findings.

31 A. Cairncross, "International Trade and Economic Development", Economica, August 1961, p. 238. 
Two, there began to appear specific logical critiques of Prebisch's reasoning. The most comprehensive of these, by Flanders, ${ }^{22}$ revealed several inherent inconsistencies in the Prebisch analysis of the tendency of the terms of trade to turn against primary products. But most damaging was Flanders' assertion that declining terms of trade were essentially irrelevant to the Prebisch case for protection and industrialisation. ${ }^{39}$ The Prebisch thesis can rest, theoretically, on the presumption of either (a) balance-of-payments difficulties, that is, imports growing faster than exports, or (b) monopoly power of LDCs in the export of primary products. (Whether these presumptions are empirically relevant is of course another question.) The Prebisch theory of deteriorating terms of trade was seen to be irrelevant in another sense as well. It has long been recognised that when the terms of trade decline through increased productivity, there is no necessary loss in welfare; the most that can be said is that a country has failed to gain all that it could. ${ }^{34}$ The relevant measure is not the barter terms of trade, but the factoral terms of trade, that is, the returns to the country's factors of production.

And three, it began to be suggested that declining LDC terms of trade, where true, were not exogenous, but were perhaps the fault of the economic structure and policies of the LDCs themselves. The suggestion began with Kindleberger, ${ }^{35}$ who felt that declining LDC terms of trade might be due to their lack of flexibility and hence to their inability to make smooth and profitable adjustments to changing economic circumstances (i.e., to switch from products whose prices are falling to those whose prices are rising). Evidence along these lines surfaces periodically as, most recently:

“... Not only do the more advanced countries (that is, those of North America and Western Europe) tend to dominate the export of the bighly income-elastic primary products, but this domination has tended to increase since the late 1930 ... the rate of downward-and-outward shift of supply curves appears to have been smaller for the primary products which the poorer countries dominate. While this supply finding cannot be confidently

${ }^{32}$ Flanders, "Prebisch on Protectionism: An Evaluation", Economic fournal, June 1964 (in Theberge, op. cit.).

33 Ibid., p. 3 I7.

34 Prebisch asserts that advanced countries appropriate the gains from productivity in their export sectors through rising wages, while the stable wages in LDCs, by allowing prices to fall, prevent the LDCs from doing the same. But as Johnson has pointed out, Prebisch confuses money wages and real wages. Real wages in both the centre and the periphery are unchanged. See H. Johnson, Economic Policies Towards Less Developed Countries, Praeger, 1967, pp. 249-250.

${ }^{35}$ In The Terms of Trade: $A$ European Case Study, Wiley, 1956. 
interpreted, it suggests that the greater ability of the advanced countries to raise productivity in primary products is part of the explanation of their increasing domination of the more incomeelastic products ...."

Simultaneously with this attack on the belief in secularly falling LDC terms of trade, another battle was raging concerning the extent and importance of cyclical instability in LDC exports. As with the terms-of-trade argument, this emerging fact has failed to offer much support to the belief, so confidently forwarded in the r950s, that the extent and consequences of export instability are greater for underdeveloped than advanced countries. Although this assertion had never long remained unscathed by its opponents' jabs, ${ }^{87}$ the empirical wounds were deepened in the early I960s. MacBean's careful examination of the instability thesis concluded:

"... the importance of short-term export instability to underdeveloped countries has been exaggerated. There is little evidence to show that in general their economies have been damaged."

MacBean does not deny that there are unstable primary products and that countries specialising in such products will have highly unstable export proceeds; but he does show that differences in the instability of export proceeds for poor and rich countries are "not large"..90 More critically, MacBean found that export instability per se had little serious repercussion on the growth and welfare of the underdeveloped countries:

"All in all, our search for evidence demonstrating the adverse influence of short-term instability of export earnings on the prospects of growth in underdeveloped countries gives us no grounds for believing that export instability is in fact so harmful. Almost every chain of reasoning leading to the conclusion that serious damage is inflicted by instability has been found wanting when confronted with analyses of UN and IMF data. Put at its weakest, the case for viewing export instability as a severe deterrent to economic growth in most underdeveloped countries is not proven. Moreover, for certain of the ways in which it is supposed to affect growth-e.g., through the quantity of investment - the weight of evidence is against." 40

${ }^{36}$ R. Porter, "Some Implications ... .", op. cit., p. 586.

37 See, for example, S. Caine, "Instability of Primary Product Prices-A Protest and a Proposal", Economic fournal, Sept. 1954.

${ }^{38}$ A. MacBean, Export Instability and Economic Development, Harvard

University Press, 1966, p. 339.

${ }^{39}$ Ibid., p. 48.

40 Ibid., p. 127. 
While MacBean's (and others') conclusions are not everywhere accepted, " they have succeeded in placing the LDC-exportinstability fear in a calmer perspective.

Also influential on LDC export attitudes and policies has been the gradual recognition that not all export instability is the exogenous result of advanced-country demand fluctuations. As recently as 1958, Nurkse asserted that:

"The parallel movement of export prices and export quantities reflects unmistakably the dominant role of demand conditions. It furnishes conclusive proof-if proof were needed-that the export fluctuations of primary producing countries originate in the world's industrial centres." ${ }_{42}$

Moreover, in the many pages of discussion of this Nurkse article, no one ever contested this basic premise. Since then, Nurkse's methodology has been challenged, ${ }^{43}$ and his claim concerning the "dominant role of demand" questioned. One recent study, for example, concludes much more cautiously.

“... for a great many commodities, it is incorrect to blame price fluctuations on either demand or supply unless very specific assumptions can be made about the short-run price elasticities of demand and/or supply."as

While the instability debate is undoubtedly far from over, its perceived importance has steadily declined and LDCs are today more aware that there are supply, as well as demand, ingredients in the problem. In short, for both the terms-of-trade and the instability debates, the point here is not who is right. It is that legitimate empirical doubts have been implanted. At the best, it has meant that export promotion is examined without preconception. But, in any case, these growing doubts have led LDCs to recognise the importance of avoiding policies that temporarily destabilise or permanently discourage exports.

\$1 See, for example, Maddison, Economic ..., op. cit., who maintains that "academic analysts have ... understated the instability problem" (p. io4).

42 R. Nurkse, "Trade Fluctuations and Buffer Policies of Low-Income Countries", Kyklos, Fasc. 2, 1958, pp. I4I-I42.

43 i.e., that "parallel movement" reflects nothing "unmistakably" is shown in R. Porter, "On Placing the Blame for Primary Product Instability", International Economic Review, Feb. I970.

4 R. Porter, "Who Destabilises Primary Product Prices ?", Indian Economic fournal, April-June 1969, p. 390. 


\section{Shifting Focus of Development Strategy}

The limitations of the import-substitution path have been increasingly recognised as more and more LDCs have pushed into its higher-cost regions. Intuitive recognition of the costliness and, more recently, measurement by means of effective protection or domestic cost of foreign exchange ${ }^{45}$ have led to the renaissance of an old-fashioned virtue: efficiency. Although it is recognised, today more than ever, that achievement of static efficiency cannot ensure rapid growth, it is also increasingly seen that the vital investable surplus, always small in a poor country, can be swallowed up by inefficiency. It is this line of thought that has induced reexamination of the often vastly different domestic cost of foreign exchange at the margin of exporting and importing.

Efficiency also has a subtler side. LDCs, which have encouraged their exporters, not only have rediscovered a relatively cheap source (in the sense of resource cost) of foreign exchange but also have received pleasant side-effects, some of those dynamic effects which were once thought to derive only from the so-called balanced growth. The process of expanding exports in one part of the economy seems to accompany greater efficiency in other sectors, perhaps because it indicates a general shift towards an efficiency-oriented government policy mix. It is of course difficult to measure such a side-effect precisely, but it is the most obvious way of explaining the high correlations between GNP and export growth.s Such a connection between GNP and export growth may also occur through saving (which after all, is one of the intersections of efficiency and growth). Economists have long suspected, and the evidence increasingly supports their conjecture, ${ }^{47}$ that exports and savings are related to each other and to efficiency and growth. Development strategy also recognises the possibility of this nexus. This recognition may

${ }^{45}$ Such measurements have been made for Turkey by A. Krueger, "Some Economic Costs of Exchange Control: The Turkish Case", fournal of Political Economy, October 1966, and Pakistan by Soligo and Stern, op. cit., and G. Hufbauer, "West Pakistan Exports: Effective Taxation, Policy Promotion, and Sectoral Discrimination", Harvard Development Advisory Service Report No. II8, 1968. For India, see Bhagwati and Desai, op. cit.

${ }^{46}$ Even more striking, GNP growth is better "explained" by exports than capacity to import. See, e.g., A. Maizels, Exports and Economic Growth of Developing Countries, Cambridge University Press, 1968, pp. 41-49.

47 See, e.g., ibid., pp. 93-96, which concludes:

"... the regression results can reasonably be taken as supporting the view ... that there is likely to be a positive association in many primary-exporting countries between exports and saving." (p. 96) 
have come in part from the declining importance of foreign controlled export firms in LDC exports, not necessarily because they no longer exist, but because they are more effectively controlled and taxed by LDC governments. The savings, which have traditionally been generated through exports, have increasingly been absorbed domestically rather than being repatriated abroad. In addition, the traditional export "enclave" has been steadily absorbed into the rest of the economy, allowing savings to flow from the export sector into the domestic economy and setting up those other linkages between exports and domestic production which balanced and unbalanced theorists had despaired of ever seeing.

A second shift in the focus of development strategy with implications for exports has been the growing concern for employment. This concern, together with the existence of excess capacity in many of the already established import-substitution industries of LDCs, has led naturally to the idea that, with exports, employment could be created beyond the output demands of the domestic market and with little need for additional investment. This is of course precisely the obverse of the thinking of early protectionists, who argued for industrialisation to create employment beyond the output demands of foreign markets, using the free labour of the disguised unemployed..$^{8}$ More generally, while there was much debate in the I950s whether LDCs should seek highly labour-intensive industry ${ }^{40}$ - in accordance with their factor endowments-the fact of the past quarter century's LDC industrialisation is that it has been shockingly capital-intensive ${ }^{50}$ and promises to be ever more so as import-substitution further encompasses high-cost, comparatively disadvantaged industries. The growing urban unemployment of LDCs, politically dangerous as well as economically wasteful, has renewed interest in the early industries of importsubstitution, usually the labour-intensive industries processing domestic raw materials and/or requiring few complex managerial or worker skills. Since output here already satisfies internal demand, this means exports. Fortunately, these long-established, labourintensive industries are usually the ones whose outputs LDCs

48 See, for instance, Prebisch, "Commercial Policy ...", op. cit., especially pp. 254, 260 and appendix.

49 The best known dissent is W. Galenson and H. Leibenstein, "Investment Criteria, Productivity, and Economic Development", Quarterly Fournal of Economics, August 1955.

so See, e.g., A.R. Khan, "Capital-Intensity and the Efficiency of Factor in Use: A Comparative Study of the Observed Capital-Labour Ratio of Pakistan Industries", Pakistan Development Review, Summer 1970. 
can hope to sell in world markets and whose demands are reasonably income-elastic. ${ }^{51}$

Many examples can be given of the kinds of products in which LDC exports are already making inroads in world trade. LDC exports rose during $196 \mathrm{I}-65$ by at least US $\$ 20$ million and the LDC share of total world trade increased for all of the following products: preserved fruits (053), ${ }^{52}$ preserved vegetables (055), shaped wood (243), inorganic chemicals (5I3), medicines and pharmaceuticals (54I), leather (6II), plywood veneers (63I), woven cotton fabrics (652), floor coverings and tapestries (657), pig iron (67I), telecommunications apparatus (724), travel goods and handbags (83I), clothing excluding fur (84I), perambulators, toys, games and sporting goods (894) and manufactured articles n.e.s. (899). Of course, not all LDCs have been equally successful participants in this growth but not all have been equally resolute. However, the number of LDCs, whose exports of manufactures and semi-manufactures to advanced countries have risen rapidly, is now sufficiently great, so that the potential has been demonstrated. For example, the following LDCs increased such exports by 50 per cent over I96I-65 to a level above US $\$ 20$ million in 19.65: Hong Kong (to US\$724 million in 1965), Mexico ( $\$ 187$ million), Taiwan (\$146 million), Brazil (\$13I million), Malaysia/Singapore (\$87 million), Philippines ( $\$ 88$ million), Pakistan ( $\$ 7 \mathrm{I}$ million), Korea ( $\$ 6 \mathrm{I}$ million), Chile ( $\$ 6 \mathrm{I}$ million), Jamaica (\$5I million), Panama ( $\$ 38$ million), UAR ( $\$ 34$ million) and Guinea ( $\$ 25$ million). ${ }^{53}$ All of these countries have claimed interest in exports and all have implemented this interest in their economic policy.

In the final analysis, the Prebisch-Singer-Myrdal thesis of "inward-looking" development failed because it did not conform to the facts. And countries that have followed its policy prescriptions have-increasingly, unfortunately and conspicuously-realised these failings. The lesson is clear: with rare exceptions (and among today's LDCs, possibly with no exception), non-dependent, yet sustained, development is impossible without significant increases in export earnings. In this paper, we have reviewed the sources from which flowed the gradual recognition of this lesson. But it should be noted, and noted well, that the better part of a quarter century

51 See, e.g., UNCTAD Secretariat, The International Division of Labour and Developing Countries, TD/40, I9 January 1968.

52 The figures in parentheses is the three-digit SITC number. Source: UNCTAD Secretariat, Review of Trade in Manufactures and Semi-Manufactures, TD/Io/Supp., I, 3I Oct. I967, Table 8.

${ }^{53}$ Ibid., Table 6. 
has been involved in this flow, and the "inward-looking" tide is, even now, not fully ebbed in the populist development writings.

We can, perhaps, draw one forward-looking lesson from this experience. The economic and political complexity of the underdeveloped world plus the magnitude of the development task have long served to disguise the essential role of exports. LDC governments and tacticians must now be discouraged from overreaction, i.e., from an excessive embrace of exports as a new panacea. Now that the critical role of exports in the development drama has been discovered-or rather, rediscovered-its lines remain to be written. Successful use of the export-oriented strategy will ultimately depend upon the LDC's ability to discover proper export products and policies. 



\section{CRED Reprint Series}

"No. 15. "Some Implications of Postwar Primary-Product Trends" by Richard C. Porter. (The Journal of Political Economy, Vol. 78, No. 3, May-June 1970, pp. 586-597)

No. 16. "Measuring the Effects of German Budget Policies, 1955-65" by Wayne W. Snyder. (Weltwirtschaftliches Archiv, Vol. 104, No. 2, 1970, pp. 302-324)

No. 17. "Politics, Privilege and Progress in Liberia-A Review Article" by Elliot J. Berg. (Liberian Studies Journal, Vol. II, No. 2, 1970, pp. 175-183)

*No. 18. "Terminal-Year Investment in Finite-Horizon Planning Models" by Richard C. Porter. (Pakistan Development Review, Summer, 1970, pp. 272-280)

*No. 19. "Measuring the Stabilizing Effects of Social Security Programs in 7 Countries, 1955-65" by Wayne W. Snyder. (National Tax Journal, September 1970, pp. 263-273)

No. 20. "Measuring Economic Stabilization: 1955-65" by Wayne W. Snyder. (The American Economic Review, December 1970, pp. 924-933)

*No. 21. "Further Comment on the Kilby/Weeks Debate: An Empirical Rejoinder" by John F. Weeks. (The Journal of Developing Areas, January 1971, pp. 165-174)

No. 22. "Structural Transformation versus Gradualism: Recent Economic Development in Ghana and the Ivory Coast" by Elliot J. Berg. (Ghana and the Ivory Coast: Perspectives of Modernization, edited by Philip Foster and Aristide R. Zolberg. Published by University of Chicago Press, 1971, pp. 187-230)

No. 23. "Budget, Economic Policy, and Economic Performance in Underdeveloped Countries" by Wolfgang F. Stolper. (Kieler Vorträge, Neue Folge 69, 1971, 33 pp.)

No. 24. "Limitations of Comprehensive Planning in the Face of Comprehensive Uncertainty: Crisis of Planning or Crisis of Planners?" by Wolfgang F. Stolper. (Weltwirtschaftliches Archiv, Vol. 107, No. 1, 1971, pp. 1-32)

*No. 25. "Managing Money and Credit in a Developing Economy" by Wayne W. Snyder. (Malayan Economic Review, Vol. XVI, No. 1, April 1971, pp. 1-12)

"No. 26. "The Control of Annual Plans: The Experience of Tunisia" by J. G. Kleve. (Journal of Modern Africa Studies, Cambridge University Press, Vol. 9, No. 2, August 1971, pp. 306-310)

No. 27. "The Rediscovery of Exports by the Third World" by Richard C. Porter and Charles P. Staelin. (Foreign Trade Review, January-March 1972, pp. 523-539)

No. 28. "Budget Policy and Economic Stability in Postwar Japan" by Wayne Snyder and Tsutomu Tanaka. (International Economic Review, Vol. 13, No. 1, February 1972, pp. 85-110) 
